\title{
Semantic classification of object phraseological units with zoonymic component in English
}

\author{
Maria Savelyeva ${ }^{1, *}$,Elena Khomutnikova $^{1}$, and Yulia Borovykh $^{1}$ \\ ${ }^{1}$ Department of Russian and Foreign Philology, Kurgan State University, 63, Sovyetskaya St., 640000, Kurgan, Russia
}

\begin{abstract}
The paper explores the least studied and, thus, the most disputable and variable aspect in describing phraseological units, which is semantics. The research is based on the semantic and grammatical analysis of 514 phraseological units with a zoonymic component in the English language collected by means of continuous sampling from the English-Russian phraseological dictionaries by professor A.V. Kunin. By analyzing lexicographical definitions, realization of the units in speech, and, in some cases, etymological aspects, we have managed to develop a hierarchy of semes in the structure of their meaning and make up a classification based on a semantic-grammatical principle. This is an essential part in the long process of compiling a dictionary of phraseological units.
\end{abstract}

\section{Introduction}

Phraseology is now a rapidly developing sphere of language study. It tends to play a central role in a wide range of linguistic disciplines such as lexicography, contrastive linguistics, psycholinguistics, foreign language learning and teaching, and natural language processing. Phraseological units represent the most colourful and expressive part of any language vocabulary. Nowadays much attention is paid to defining a clear borderline between free word combinations and phraseological units, to classifying phraseological units on the basis of their semantic and/or grammatical characteristics, to corpus-based analysis of phraseology, and computational approach to lexicographical description and translation of phraseologisms.

Semantic aspects of phraseological study have always been of great interest to both Russian and foreign scholars. The analysis of the latest publications and studies in the problematic sphere shows that there is a definite tendency to semantic-grammatical and lexicographical description of phraseological units in one (mainly, native) language and its dialectal variations and lexicographical and comparative description of phraseological units in two or more languages regardless of their genetic relationship. Prof. Mokienko V.M. together with other lexicographers of Saint Petersburg University implement the concept of a complete dialect dictionary in a new interpretation where dialect phraseology will be presented against a nationwide phraseological background through the use of the material of fiction, folklore, media text, slang dictionaries, records of modern speech and survey data [1]. Maria Stefanescu and Doris Sava, both dealing with the Romanian language, consider it imperative to create modern phraseological dictionaries that would be more reliable and user-friendly than the existing works [2, 3]. Scholars of Kazan Federal University have recently managed to enunciate the general principles of compiling a dictionary of phraseological antonyms as well as the principles of lexicographical description of phraseological antonyms for both the monolingual and bilingual dictionaries [4].

After Prof. Lebedinskaya V.A., in our research we identify phraseological units as independent nominative language units that differ from words or free word combinations and are characterized by having such features as relative syntactic stability and invariability (no word can be substituted for any component of a phraseological unit without destroying its sense), semantic unity (they convey a single concept and their meaning is idiomatic and in most cases figurative, i.e. it is not a mere total of the meanings of their components), multiwordness (they have a structure of two or more separate components), and integrated reproductivity in speech (they are not created in speech but used as readymade units) [5].

The objective of the paper is to present the results of the current stage of our research which, in general, aims at semantic-grammatical classification and lexicographical description of phraseological units with various components. One of the most productive components used in the structure of phraseological units is the one naming animals, or zoonym. The survey of the latest research shows that phraseological units with zoonymic components are widely studied in different languages. Russian scholars in cooperation with their foreign colleagues conduct a detailed study of phraseological units with various zoonymic components in Russian, German, English, Italian, Spanish, Chechen, Chinese, and Thai languages to disclose the cultural impact on the cognitive concepts in languages with

\footnotetext{
*Corresponding author: t_maria@mail.ru
} 
different range of genetic relationship [6-10]. The relevance of further detailed studies of phraseological units with zoonymic components arouses little doubt, since zoo-phraseologisms are widely used among native speakers and their adequate interpretation and translation are required in a vast majority of cases to avoid misunderstanding in the process of communication.

This article conveys the classification based on the semantic and grammatical analysis of 514 phraseological units with zoonymic component in the English language collected by means of continuous sampling from the English-Russian phraseological dictionaries by Prof. Kunin A.V. [11]. They can be divided into six major semantic-grammatical classes: object phraseological units -209 units $(41 \%)$, processual - 198 units $(38 \%)$, attributive-predicative - 80 units $(15.5 \%)$, qualitativeadverbial -21 units (4\%), modal -7 units (1.4\%), and quantitative -1 unit $(0.1 \%)$. Within the given survey we are going to present the semantic classification of object phraseological units.

\section{Results and Discussion}

In the sphere of phraseology the semantic categories of animacy and person are closely connected with the reality. Our classification is based on the opposition "animacy vs. inanimacy" that reveals the division of the reality into the worlds of animate and inanimate things. The category of person is considered to be a distinct feature of phraseological units identifying the man. Thus, the group of object phraseological units with subcategorical meanings of animacy and person includes anthroponyms while those with subcategorical meanings of animacy and non-person include units nominating animals and mythical creatures. The group of object phraseological units with subcategorical meanings of inanimacy and non-person include three subgroups of phraseological units denoting a) substances, b) concrete things, and c) abstract phenomena. Within each subgroup there can be distinguished individual subsubcategories.

Nouns and adjectives play a major role in building up the semantics of phraseological unites with zoonymic component in English. Nouns being major grammatical components supply the semantic structure of phraseological units with the categorical seme of objectness and subcategorical semes of animacy / inanimacy and person / non-person. Other grammatically subordinate components supply group and individual semes.

\subsection{Units denoting animate or inanimate objects}

Out of the 209 object phraseological units there are 11 denoting animate or inanimate objects, and it is expressed in their lexicographical description:

the cat's meow "someone or something wonderful or remarkable"; a Trojan horse "someone or something intended to defeat or subvert from within usually by deceptive means"; a sacred cow "a person or thing that is never criticized, laughed at, or insulted even if it deserves such treatment"; the big bad wolf "threatening or sinister person or thing", etc.

The main grammatical component is usually expressed by such zoonyms as horse, cow, duck, fly, wolf which supplies the semantic structure of phraseological units with the categorical seme of objectness and subcategorical semes of animacy / inanimacy and person / non-person. Let us see how the semantic features are revealed in speech.

For example, "Tories... regard rent, interest and profit as sacred cows to be fattened at the expense of the people" ('Daily Worker', Nov. 25, 1961).

In the given example the categorical seme of objectness and subcategorical semes of animacy (to be fattened) and non-person (rent, interest and profit) are clearly manifested making the statement highly expressive.

\subsection{Units denoting living creatures}

About half of all the object phraseological units with zoonymic components (101 units in total) denote living creatures. The analysis of their lexicographical definitions and contextual realization showed that they can be classified into three semantic clusters:

1) units nominating people, or "anthroponyms";

2) units nominating animals;

3) units nominating mythical creatures.

\subsubsection{Units nominating people}

Having the subcategorical seme of animacy, object phraseological units with zoonymic components name a person in the vast majority of usages. There have been distinguished 90 units denoting people. They tend to be called "anthroponyms", or according to terminology of Prof. Ratushnaya E.R. they can be called "anthropnominations" [12]:

a dirty dog "a low and sneaky person"; a willing horse "a person prepared to work hard"; a wolf in sheep's clothing "a dangerous person pretending to be harmless"; a bull in a china shop "an extremely clumsy person"; a fighting cock "a pugnacious person"; a big bug "an important person"; a fish out of water "one who does not feel comfortable in a new environment", etc.

Phraseological units nominating a group of people or a unity can also be found within this semantic cluster:

Kilkenny cats "people who fight relentlessly till their end"; birds of a feather "people who are similar in character"; a hen party "a group of women at a party for a woman who is going to get married soon", etc.

The grammatically main component is expressed by a zoonym that, due to its direct lexical meaning, forms the categorical and subcategorical semantics of the whole phraseological unit. The subcategorical seme of the person is manifested in the semantic structure of a unit to identify a human being characterized by some definite features.

I am doing my best and it's no good flogging $a$ willing horse? (A. Trollope, 'The Way We Live Now'). Members of Parliament and ladies of fashion, like 
himself and Fleur... now and then... going for each other like Kilkenny cats (J. Galsworthy, 'The Silver Spoon').

\subsubsection{Units nominating animals}

The cluster of phraseological units denoting animals, mainly birds, includes 9 units:

the king of beasts "a lion"; the bird of Jove "any of various large keen-sighted diurnal birds of prey noted for their broad wings and strong soaring flight"; the bird of Juno "very large terrestrial southeast Asian pheasant often raised as an ornamental bird"; the bird of Minerva "nocturnal bird of prey with hawk-like beak and claws and large head with front-facing eyes"; a bird of paradise "any of numerous brilliantly colored plumed birds of the New Guinea area"; a bird of prey "a bird, such as an eagle or a hawk, that kills and eats small birds and animals"; the king of birds "the eagle"; the bird of peace "a figurative name for dove"; Mother Carey's chicken "a petrel, especially a storm-petrel".

The lexeme "bird" as a component of phraseological units provides their semantic structure with categorical and subcatogorical semes. In the some units we find names of ancient Roman gods: Jove, also known as Jupiter, is the god of the sky, daylight and thunder, and king of the gods in Ancient Roman religion and mythology. His identifying implement is the thunderbolt and his primary sacred animal is the eagle; Juno, Jove's wife, is the protector and special counselor of the state, the patron goddess of all the women of Rome, the goddess of marriage and motherhood, her sacred animal was the peacock. Minerva is the Roman goddess of wisdom and strategic warfare and the sponsor of arts, trade, and strategy, she is also the virgin goddess of music, poetry, medicine, wisdom, commerce, weaving, and the crafts, she is often depicted with her sacred creature, an owl which symbolizes her association with wisdom and knowledge.

The life, with which the sea teems, especially in the tropics, also did much to dispel monotony from the sailor's life. The endless shoals of herring... and also the Mother Carey's chicken... The huge pelicans and especially the king of them all, the great Southern albatross (W. Foster, 'Pages from a Worker's Life').

\subsubsection{Units nominating mythical creatures}

There have been only two phraseological units denoting mythical creatures:

- the Arabian bird "the phoenix, a fabulous bird that after a life of five or six centuries immolates itself on a pyre and rises from the ashes to begin a new cycle of years: often an emblem of immortality or of reborn idealism or hope".

The component "bird" actualizes the semes of objectness, animacy and non-person. The component "Arabian" actualizes the seme "related to Arabia" and denotes the origin of the mythical bird. The phoenix is associated with the Sun and depicted in many cultures as having an ability to obtain new life by arising from the ashes of its predecessor. It is the symbol of renewal and immortality. In the historical record, the phoenix could symbolize renewal in general as well as the sun, time, the Empire, consecration, resurrection, life in the heavenly Paradise, Christ, Mary, virginity, the exceptional man, and certain aspects of Christian life.

- Lamb of God "a title given to Christ in the New Testament, probably with reference to his sacrificial death". It originates from the Bible. Though mainly used as another name of Jesus Christ, it can also denote a humble person with a clear soul. Lamb of God is one of the main Christian symbols primarily of Catholic Church [13].

\subsection{Units denoting inanimate things}

Phraseological units denoting inanimate things are quite numerous in English. There have been distinguished 97 units which name concrete / actual things, substances, and abstract phenomena.

\subsubsection{Units denoting concrete things of actual reality}

There have been 16 units with the zoonymic component denoting concrete things of actual reality though it is not typical of phraseological units:

a dead dog "a thing of no use or value"; the iron horse "a railroad locomotive"; the lion's mouth "a dangerous place", a blind tiger / pig "(informal, archaic) an illegal bar where alcohol was sold during prohibition laws in mid-19th century (probably so named to evade, the bars being disguised as exhibition halls for the display of natural curiosities)", etc.

We opened up on some of the worst dives and blind tigers by name... The attack created a howling sensation (S. Lewis, 'Elmer Gantry').

The object phraseological units with zoonymic components naming concrete things of actual reality can be divided into three semantic subgroups:

a) 7 units denoting artifacts made by people and used in every-day life:

the cow with the iron tail "a machine that dilutes milk with water"; teddy bear "a stuffed toy bear made from soft or fluffy material" (in early 20th century: from Teddy, pet form of the given name Theodore, alluding to Theodore Roosevelt, Theodore, an enthusiastic bearhunter who once refused to shoot the black American bear); a kangaroo ticket "a ticket for an election in which the lower position is occupied by a more attractive candidate than the higher position"; zebra crossing "a pedestrian crosswalk"; soup and fish "a man's formal evening clothes" (so named from the traditional first two courses of a formal dinner); the iron horse "a railroad locomotive"; a cat o' nine tails"(historical) a rope whip with nine knotted cords, formerly used (especially at sea) to flog offenders and known for leaving scratches identical to those from cats' nails".

Go home and doll up in your soup and fish, Paul, and wipe that worried look off your map Tonight we gamble (E. S. Gardner, 'The Case of the Dangerous Dowager'). 
b) 6 units denoting places or territories can be used to name or identify

- a certain position or location:

horse latitudes "either of two belts or regions in the neighborhood of $30^{\circ} \mathrm{N}$ and $30^{\circ} \mathrm{S}$ latitude characterized by high pressure, calms, and light variable winds"; blind tiger / pig "a place where alcoholic beverages are sold illegally; a speakeasy"; crow's nest "platform for a lookout at or near the top of a mast";

- any place characterized by a certain feature: the lion's mouth "a dangerous place";

- a definite state: the British Lion "Great Britain".

She (Chicago) is young, and may be forgiven her conceit when even our elder, the British Lion, has not yet outgrown it (R. Kipling, 'American Notes').

c) 3 units denoting natural phenomena like stones, wind, and water:

a cat's eye "any of various gems that reflect light when cut in rounded shape"; cat's paw "a light breeze that ruffles small areas of water surface"; white horses (caps) "waves that break into small white bubbles at their highest point".

\subsubsection{Units denoting substance}

There have been distinguished 7 units with the zoonymic component with the sub-subcategory of substance denoting:

- alcoholic beverages:

a hair of the dog (that bit one) "(informal, colloquial) an alcoholic drink taken in the hope of countering the effects of a recent overindulgence in alcohol"; dog's nose "(jargon) a mixed drink of malt liquor and spirits; especially: a hot drink of spiced porter laced with gin or rum"; a horse's neck "an American cocktail made with brandy (or sometimes bourbon) and ginger ale, with a long spiral of lemon peel (zest) draped over the edge of an old fashioned or highball glass"; Cold Duck "a beverage made of sparkling Burgundy and champagne".

- food: salt horse "(jargon) salted meat (as beef or pork)"; the fatted calf "best calf killed for feast to celebrate return of prodigal son".

Three times the galley had been washed out, and the men... contented themselves with hard tack and cold salt horse (J. London, 'The Mutiny of the 'Elsinore').

\subsubsection{Units denoting abstract phenomena}

The most numerous group is presented by phraseological units with the zoonymic component denoting abstract phenomena ( 74 units in total). It is quite characteristic of phraseologisms to identify some abstract concepts. Here we distinguish four semantic groups:

a) 12 units denoting activity. Here we mainly find phraseological units with zoonymic component naming games and other playing activities:

hare and hounds "a game in which one group of players leaves a trail of paper scraps for a pursuing group to follow"; pigs in clover "game played by tilting a small box containing holes and marbles so that every marble will roll into a hole"; ducks and drakes "the game of skipping flat stones along the surface of water"; red dog "a game of poker"; kangaroo court "an unfair, biased, or hasty judicial proceeding that ends in a harsh punishment", etc.

Mrs. Wiseman said, 'Let's play red dog for pennies. I've got a few dollars left' (W. Faulkner, 'Mosquitoes').

b) 53 units denoting different types of abstract phenomena or situations or actual reality:

a wildcat strike "a labor strike that has not been called or sanctioned by the officials of the union"; monkey's allowance "something that yields more abuse than reward"; a black swan "a phenomenon that occurs even though it had been thought to be impossible"; $a$ dog's dinner / breakfast "(informal) something that is messy or bungled; a poor job; a mess"; a red dog "a game of chance played with cards"; dog eat dog "a situation of fierce competition in which people are willing to do anything in order to succeed, even if what they do harms other people"; a cat in the meal "something concealed; a hidden danger"; horse opera "a story, movie, or radio or television play about the US. West of the 19th century"; monkey business "silliness; dishonest tricks"; donkey's years "a long time"; the cat among the pigeons "a situation in which something causes trouble and makes a lot of people angry or worried"; the cat-and-mouse game "a situation characterized by two parties engaged in a constant backand-forth routine in which the advantage alternates between them"; a horse of a different (or another) colour "a situation or a subject that is different from what you had first thought it was" and many more.

It was no place for novices. It was $\operatorname{dog}$ eat $\operatorname{dog} \ldots$ (W. $\mathrm{Du}$ Bois, 'The Ordeal of Mansart'). Wildcat strikes are more numerous in this particular field than in any other category of industry or business ('New York Herald Tribune'). I speak of the generality, not of the few black swans among us. (J. Galsworthy, 'Another Sheaf', 'American and Briton'). Some of the men plan to kill you,' said his father. 'They don't mean any monkey business. They're as mad as hornets' (V. Fisher, 'Children of God').

c) 5 units denoting state or condition:

a hang-dog air "a self-pitying expression of abjection, defeat, shame, or guilt"; a constitution like of a horse "a good health"; monkey business "silliness"; animal spirits "the vitality of good health"; an eagle eye "keen eyesight".

..for some time she did like them captivated by the flare and show and animal spirits of this realm (Th. Dreiser, 'A Gallery of Women'). She could not remember having felt so happy... so full of just plain healthy animal spirits, since before she was married (J. Jones, 'From Here to Eternity').

d) 4 units denoting rational concepts like life and death:

a dog's death "a miserable end; often: a dishonorable or shameful death"; a dog's life "a miserably unhappy existence"; a cat-and-dog existence "a life together typified by arguments, fights, and disagreements"; rat race "the unpleasant life of people who have jobs that require them to work very hard in 
order to compete with others for money, power, status, etc."

If he is unhappy with her... why doesn't he leave her? She can be happy without him. It is so silly - this catand-dog existence (Th. Dreiser, 'The Titan').

As it is seen from the given examples, the zoonymic components 'dog', 'cat', 'rat' are not grammatically main (they are not headwords of the phraseological units) and function as subordinate elements used in preposition as attributes. Due to their negative connotation they provide the semantic structure of phraseological units with such semes as 'unsatisfactory', 'poor in quality', 'worthless', 'unpleasant', 'unhappy'.

\section{Conclusion}

Object phraseological units are greater in number than any other semantic-grammatical type of phraseological units with zoonymic components in the English language. This fact emphasizes the common tendency among native English speakers to denote things, substances and phenomena of the reality by means of descriptive language units for a special emotional effect. Within the group of units with the subcategorical seme of animacy the most numerous is the cluster of units denoting people - "anthroponyms" or "anthroponominations". It can be explained by the anthropocentred or human-centred character of the phraseological units which are mainly used to name a person according to their specific features. Moreover, within the group of units with the subcategorical seme of inanimacy, object phraseological units denoting concrete things of actual reality prevail in comparison with the number and frequency of those denoting abstract phenomena.

\section{References}

1. V.M. Mokienko, T.G. Nikitina. Voprosy Leksikografii - Rus. J. of Lex. 14, 80 (2018)

2. M. Stefanescu. Dacoromania 22, 51 (2017)

3. D. Sava. Lexikos 27, 457 (2017)

4. O.A. Bezuglova, F.H. Tarasova, M.S. Pestova, L.G. Ilyasova. Mod. J. Lang. Teach. Methods SI, 151 (2016)

5. V.A. Lebedinskaya. Protsessualniye phraseologuismy sovremennogo russkogo yazyka (Cheliabinsk, 1987)

6. E.V. Varlamova, A.E. Rakhimova, A.S. Shingareva. Revista Publicando 4, 477 (2017)

7. S.Y. Glushkova, T. Chitra, Ad Alta - J. Interdisc. Res. 8, 181 (2018)

8. L.N. Gishkaeva, J.N. Ebzeeva, N.V. Dubinina, V.V. Barabash, A.N. Shirobokov. Sibirskii Filologicheskii Zhurnal 3, 151 (2017)

9. Y.N. Kulichenko, E.M. Korolevskaya. Nauchnyi Dialog 4, 44 (2017)

10. J Baghana, E. Iakovleva. Vestnik Rossiiskogo Universiteta Druzhby Narodov - RJL 20, 91 (2016)

11. A.V. Kunin. Anglo-Russkii phraseologuicheskii slovar (Moscow, 1984/1999)

12. E.R. Ratushnaya. Semanticheskaya struktura phraseologuismov $v$ protsesse eyo formirovania $i$ functsionirovaniya (Kurgan, 2000)

13. E.A. Khomutnikova, Yu.S. Borovykh. Agrar. obraz. nauka 2, 25 (2017) 